\title{
Internationales Privatredht
}

\author{
Ein Grundriß \\ von \\ Dr. Karl Neumeyer \\ Geh. Justizrat, o. Professor des internationalen Privatrechts \\ an der Universität Mündien
}

2. Auflage

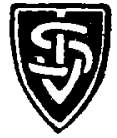

1930

München, Berlin, Leipzig

J. Schweitzer Verlag (Arthur Sellier) 



\title{
Internationales Privatrecht
}

\author{
Ein Grundriß
}

von

Dr. Karl Neumeyer

Geh. Justizrat, o. Professor des internationalen Privatredts an der Universität Münhen

2. Auflage

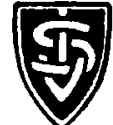

1930

München, Berlin, Leipzig

J. Schweitzer Verlag (Arthur Sellier) 
Druck von Dr. F. P. Datterer \& Cie., Freising-München. 